\title{
Effects of development on indigenous dietary pattern: A Nigerian case study
}

\author{
by Bookie, E. and Farag, K.
}

Copyright, Publisher and Additional Information: This is the author accepted manuscript. The final published version (version of record) is available online via Elsevier Please refer to any applicable terms of use of the publisher.

DOI: 10.1016/j.appet.2016.07.025

Harper Adams

University 


\section{Accepted Manuscript}

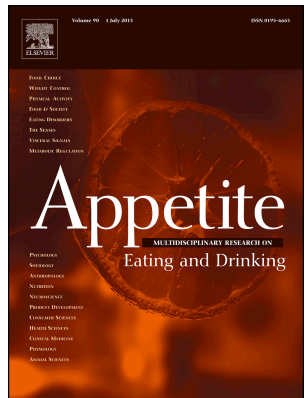

Effects of development on indigenous dietary pattern: A Nigerian case study

Bookie Ezeomah, Karim Farag

PII: S0195-6663(16)30292-6

DOI: $\quad$ 10.1016/j.appet.2016.07.025

Reference: $\quad$ APPET 3082

To appear in: Appetite

Received Date: 26 February 2016

Revised Date: 18 May 2016

Accepted Date: 18 July 2016

Please cite this article as: Ezeomah B. \& Farag K., Effects of development on indigenous dietary pattern: A Nigerian case study, Appetite (2016), doi: 10.1016/j.appet.2016.07.025.

This is a PDF file of an unedited manuscript that has been accepted for publication. As a service to our customers we are providing this early version of the manuscript. The manuscript will undergo copyediting, typesetting, and review of the resulting proof before it is published in its final form. Please note that during the production process errors may be discovered which could affect the content, and all legal disclaimers that apply to the journal pertain. 


\section{Effects of Development on Indigenous Dietary Pattern: A Nigerian case study}

\section{Bookie Ezeomah ${ }^{1}$, Karim Farag ${ }^{2}$}

${ }^{1}$ School of Agriculture, Food and Environment, Royal Agricultural University, United Kingdom.

${ }^{2}$ Department of Food Science and Agri-Food Supply Chain Management, Harper Adams University, United Kingdom

\section{Corresponding Author:}

Dr Karim Farag

Senior Lecturer in Food Science and Management Food Science and Agri-Food Supply Chain Management Harper Adams University

Newport

Shropshire

TF10 8NB

UK.

Email: kfarag@harper-adams.ac.uk

Tel: +44 (0) 1952815167 


\section{ACCEPTED MANUSCRIPT}

\section{Effects of Development on Indigenous Dietary Pattern: A Nigerian case study}

\section{Abstract}

The traditional foods of indigenous people in Nigeria are known for their cultural symbolism and agricultural biodiversity which contributes to their daily healthy and rich diet. In the early 90s, rapid development of the Federal Capital Territory (FCT) was noted and the resettlement of indigenes to other parts of the region was reported. These changes have facilitated the modification of indigenous diets, as indigenous groups rapidly embraced modern foods and also adopted the food culture of migrant ethnic groups. This has led to a gradual erosion of indigenous diets and traditional food systems in the FCT. This study explored the impact of development on traditional food systems and determined indigenes perception of the modification to their food culture as a result of the development of their land within the FCT. Field survey was carried out in four indigenous communities in the FCT (30 indigenes from each of the four areas) using structured questionnaires, Focus Group Discussions (FGDs) and key informant interviews. Person Chi Square analysis of indigenes socio-economic characteristics revealed significant relationships between gender of indigenes and farm size, Age and farm size, Educational level and farm/herd size. Qualitative analysis of FGDs revealed indigenes opinion on the socio-cultural changes in behaviour and food systems as a result of development. The study also identified indigenous youths as being most influenced by development especially through education, white collar jobs and social interactions with migrant ethnic groups in the FCT. The study recommended that indigenes should be provided with more secure land tenure and "back-to-farm" initiatives should be put in place by the Nigerian government to encourage indigenous youth to engaged more in agriculture.

Keywords: Traditional Food; Diet; Indigenous groups; Culture; Development; Nigeria; FCT 


\section{Introduction}

2 In most parts of sub-Saharan Africa, the traditional food systems of indigenous people are characterised by rich agricultural biodiversity which contributes immensely to satisfying daily food needs and providing secure livelihoods (Mendez et al., 2005). Hobblink (2004) also added that, in developing countries, the greatest biodiversity is found in rural communities where there is a great dependence on the environment and natural resources for nutritive sustenance. Therefore a sustainable means of promoting food security and nutrition in developing countries is to ensure the viability of their traditional food systems (Smith, 2013).

As documented in literature, factors such as, education, food prices, income, political climate and food availability are some of the key drivers of food security and nutrition (Pieters et al., 2013; O'Connor et al., 2016). However, the role of culture and the traditional food systems especially among indigenous people in promoting their food security and nutrition have not been as widely documented as the previously mentioned key drivers.

According to Briones (2015), culture shapes food preferences of a group by laying down rules and regulations that determine the acceptance or rejection of certain foods. She added that culture also determines the food production systems, roles and responsibilities in food preparation as well as methods for intra-household food distribution, all of which significantly impacts the food and nutrition security status in the household. Furthermore, indigenous people have been identified as the custodians of traditional knowledge. As such, culture and traditional food systems passed down from previous generations have come to serve as a blueprint for natural resource use and management, which contributes to the sustainability of their food production systems and environment (Kuhnlein et al., 2013).

In 1991, the seat of the Nigerian Federal Government moved from Lagos to Abuja resulting in a rapid development of the area and resettlement of indigenes to other parts of the Federal Capital Territory (Adama, 2007). Abuja has also been identified as the fastest growing city in West Africa (LeVan and Olubowole, 2014).

This research is based on two indigenous groups within the Federal Capital Territory (FCT) of Nigeria called the Gbagyi (also known as Gwari or Gbari) and Bassa. The research aims to provide an understanding of traditional food systems of indigenous groups in the FCT, determine the extent to which the development of their native land into Federal Capital Territory has influenced their traditional food system and identify indigenes perception of the impact of development on their traditional food system. The research also aims at identifying the key drivers of development that have brought about these changes in food culture and 
1 provide recommendations on ways that culture can inform development efforts going

2 forward.

32 Research Methodology

\section{$4 \quad 2.1$ Study Area}

5 The study area is the Federal Capital Territory (FCT) of Nigeria, located within $9.2^{0} ; 9.6^{0} \mathrm{~N}$ 6 and $6.8^{0} ; 7.2^{0} \mathrm{E}$ in the heart of the Southern Guinea Savannah (Chuwang et al., 2014)

7 (figure 1). The FCT is divided into six area councils namely; Municipal, Abaji, Bwari, 8 Gwagwalada, Kuje and Kwali area councils (figure 2). The Gbagyi and Bassa indigenes within Gwagwalada and Kuje area councils were selected for this research. As the original settlers in the FCT, the Gbagyi's are considered to be the dominant indigenous group and the Gbagyi language is widely spoken in the region. Other indigenous groups in the FCT are Bassa, Koro, Kadara, Bassankomu, Gade, Ganagana-Nupe, Kurama, Hausa (Maguzawa), Zuru and Kamberi. The major occupations engaged in by these groups are farming, pottery, blacksmith, hunting and woodcutting. These indigenous groups can also be found in other states around the FCT such as Kaduna, Nassarawa and Niger (Filaba, 2008).

\section{Placement of Figure 1}

Gwagwalada has a population of about 157, 770 (NPC, 2006) and occupies a land area of 1,043 square kilometres. The indigenes of Gwagwalada are mainly Gbagyi, Bassa, HousaFulani, koro and Gede. The two communities selected for this research were Bargada (inhabited by Gbagyi indigenes) and Kaida (inhabited by Bassa indigenes) (Nkechi and Paul, 2012). Kuje has a population of approximately 97,367 (NPC, 2006) and occupies a land mass of about 1,800 sqkrn. Like Gwagwalada, Kuje is inhabited by several indigenous groups including; Gbagyi, Bassa, Egbirakoto, Gade, Hausa-fulani and others (Jimme et al., 2015). The two communities selected from Kuje were Chukuku (inhabited by Gbagyi indigenes) and Sketuko (inhabited by Bassa Indigenes).

\section{Placement of Figure 2}

\subsection{Sampling Techniques}

A combination of random and purposive sampling was adopted for this research (see figure 3). Using a ballot system, two out of the six area councils in FCT were selected. In each of these area councils, two communities were purposively selected (one Gbagyi and one Bassa) based on the timeliness of response received from village heads. The research was carried out at the peak of their farming season and there was noticeable reluctance to partake in the survey, for this reason, 30 households in each community were selected based on their willingness and availability to fill questionnaires and participate in focus group 
1 discussions. The total sample size was 120 respondents from four communities in two area

2 councils.

3 The fieldwork started with a submission of a letter to Gwagwalada and Kuje area councils 4 which was forwarded (and explained) to the village heads. This was followed by an invitation 5 by the village heads. The field work employed a combination of structured questionnaires, 6 focus group discussions, key informant interviews with village heads and elders and 7 photographic documentation with the permission of respondents. To bridge the language 8 gap and ensure accuracy in translating responses from local Gbagyi and Bassa dialects to 9 English, three translators who spoke both English and Gbagyi dialect were used for interviews in Gbagyi communities and another three translators who spoke English and Bassa dialect were used for interviews in the Bassa communities, and one translator who spoke English and Hausa ${ }^{1}$ was also used though out the field survey. Responses to questions for this research were provided by respondents in Gbayi, Bassa, Hausa or English languages. However, responses to questionnaires which were provided in Gbayi, Bassa and Hausa dialects were written down in English by the translators. Villages selected for this research were Bargada-BD (Gbagyi) and Kaida-KD (Bassa) in Gwagwalada area council and Chukuku-CK (Gbagyi) and Shetuko-SK (Bassa) in Kuje area council.

\section{Placement of Figure 3}

\subsection{Data collection}

Both primary and secondary data were used for this research. Primary data was gathered using structured questionnaires, Focus Group Discussions (FGDs) and key informant interviews (with village heads/elders). Field data collection was carried out over four months (between June and September). The first two weeks of the field study was used to train translators on questionnaire administration and response recording. This period was also used as an opportunity to test the questionnaires and FGD interview guide on 20 respondents (5 respondents in each of the selected communities). The pilot revealed that questionnaire was too long because it took more than 90 minutes to complete each questionnaire. Also because respondents were not able to accurately recall previous meals eaten during the week, quantity and quality of meals (in terms of what extra classes of food included to meals), the food security section of the questionnaire was excluded. Therefore, the piloted questionnaire which contained 35 questions was reduced to 20 questions and research questions were also re-evaluated. Educated respondents filled out the questionnaires themselves in English, while the responses of uneducated respondents were recorded by translators in English.

\footnotetext{
${ }^{1}$ Hausa is a common second language spoken by indigenous groups in FCT.
} 
1 Focus group discussions were also carried out by the researcher and translators using

2 an interview guide made up of 20 questions and a Dictaphone to record responses. One

3 session of FGD was carried out in each community, resulting in a total of 4 sessions

4 FGDs. Each FGD lasted approximately 60 minutes, with 10 respondents in each group.

5 Each group was made up of an uneven mix of men and women based on willingness

6 and availability to participate. Questions were asked by the researcher in English then

7 translated to the local dialect by a translator. Responses were provided in Gbagyi,

8 Bassa or Hausa dialect depending on the community. At the end of each FDG and key

9 informant interview, the researcher and translators listened to recorded sessions and transcribed to English. The research employed more than one translator in both questionnaire administration and FDGs to ensure accuracy in obtaining responses from non-English speaking respondents as well as in recording the correct of spellings of local foods and drinks. Data collected from the field survey were used to derive the socio-economic status of individual households and the socio-cultural profile of the Gbagyi and Bassa indigenous groups especially with regards to their traditional food systems. The secondary data used in this research include the population and land mass of the area councils selected as well as the West Africa food composition tables (FAO, 2012) used to determine the nutritional content of food consumed by respondents.

\subsection{Data Analysis}

Data recording and analysis were carried out in English. Various techniques were used to analyse both quantitative and qualitative field data. To analyse quantitative data, descriptive statistics such as percentages, averages, tables and graphs were used. Some qualitative data were also used for cross tabulation to derive relationships between variables (Witte and Witte, 2004). Statistical Package for Social Sciences (SPSS) was used to obtain a Pearson Chi Square value to determine the presence or absence of statistical significant relationships between variables (Arkkelin, 2014). Data obtained from FDGs were analysed and coded qualitatively using NVivo9 software to identify key themes that explained the socio-cultural characteristics of indigenous groups and their perception of developmental impacts on indigenous food culture.

\section{Results and Discussion}


13.1 Socio-economic characteristics of respondents

\subsubsection{Gender and educational level of respondents and dependents ${ }^{2}$}

Gender can be a common barrier to equal access to education for boys and girls in indigenous groups (UN 2010). Figure 4 (a) reveals that 41 out of the 120 sampled respondents had no formal education and $10 \%$ were male while $24 \%$ were female. It should however be noted that there were more female than male respondents. But the study showed that $66 \%$ of the entire sampled respondents have had some form of formal education. The reason for the relatively high percentage of sampled respondents that have had some level of education can be attributed to the adult literacy development projects (Odumuh, 2003) which have been instituted in several indigenous communities in FCT including communities in Gwagwalada and Kuje area councils.

\section{Placement of Figure 4}

Figure 4 (b) also shows the rate of school attendance among dependents. Again, there were more female than male dependents in this study from which $27 \%$ female dependents had at least primary education compared to $20 \%$ male dependents. However, despite the higher number of total female dependents, $22 \%$ and $4 \%$ of the male dependents had obtained secondary and tertiary education respectively while $16 \%$ and only $2 \%$ of the female dependents had obtained secondary and tertiary education respectively. These figures reflect the change in the dynamics of education after primary level as more males than females are encouraged to attain a higher level of schooling.

The results from figure $4 \mathrm{a}$ and $\mathrm{b}$ are in agreement with Alabi and Alabi (2014) who opined that the girl-child is more susceptible to certain geographic, cultural, religious and economic constraints in obtaining education than the male child in Nigeria. However, the results also show that majority both Gbagyi and Bassa Indigenous children have been exposed to some level of formal education. The increased rate of rural children school attendance, especially female children, can be attributed to the Universal Basic Education which was instituted 1999 to provide free, universal and compulsory basic education for every Nigerian child between the ages of 6 and 15 years (Amuchie et al, 2015). This has increased opportunities for females to gain primary and junior secondary education at decreased cost to parents and guardians.

\footnotetext{
${ }^{2}$ Dependents include all individuals within a household who are under the direct care of the respondent. This includes biological and non-biological dependents but excludes biological children who live elsewhere or who are married
} 
$1 \quad 3.1 .2$ Gender and farm size ${ }^{3}$

2 The results also show there is a significant relationship between gender and farm size $\left(\mathrm{Chi}^{2}\right.$ $p<0.05)$. Although gender inequality in the use and ownership of production resources has been identified as one of the key problems with agriculture in Nigeria (Olagunju et al., 2012), all 73 female respondents had access ${ }^{4}$ to land for their farming activities in the study area. This is consistent with the findings of Julius (2014) in his "evaluation of gender assess to farm inputs in Abuja, Nigeria". He recorded that there was no significant difference between male and female access to farm inputs, including land, among indigenes of the FCT.

\section{Placement of Table 1}

The field survey however revealed that while gender did not influence access to farmland, the size of farmland men and women has access to could be influenced by gender. As shown in table 1,72\% respondents cultivated less than a hectare of farmland were women, yet in contrast, $82 \%$ male respondents cultivated over 5 hectares of farmland compared to $18 \%$ women. The influence of gender on farm size can be attributed to the patriarchal system of most African communities where women have access to farmland from their husband who may have more than one wife. As a result of polygamy, land fragmentation to meet the food production needs of wives may also be the reason for female access to small parcels of land than men (Ngodoo and Idisi, 2014).

\subsubsection{Age and farm size}

The results show a significant relationship between age and farm size $\left(\mathrm{Chi}^{2} \mathrm{p}<0.05\right)$. There were $13 \%$ respondents below 30 years of age and $23 \%$ of them cultivated less than 1 hectare. As shown in table 1, 44\% respondents fell between the ages of 30-50 years with $52 \%$ of them cultivating less than 1 hectare, $45 \%$ of them cultivating $1-5$ hectares and none of them cultivating above 5 hectares of farmland. The only age group that cultivated above 5 hectares were those above 50 years of age. They accounted for $43 \%$ of the total sample.

The decrease in the area of land cultivated with a decrease in age can be attributed to the fact that younger people who live in indigenous communities tend to have other white and blue collar jobs in urban areas. Also, with the increasing educational level of many young indigenes, as discussed previously in section 3.1.1, farming has become a secondary source of income and is therefore seen as less convenient than white collar jobs. These findings are consistent with Pam (2014) who reported that rural-urban migration among Nigerian youths in search of "better sources of livelihoods" has influenced the level of agricultural activities in

\footnotetext{
${ }^{3}$ Farm size here means area of land in cultivation or on which animals are raised, not area of land owned but not yet used for agricultural purposes (land owned may be greater or equal to farm size)

${ }^{4}$ Access is not ownership. The land Use Act of 1978 gives custody of all land to the state government and in the case of FCT to the Federal government
} 
1 rural areas, as less land is being cultivated and farming activities are carried out for aged

2 and weaker groups.

\section{$3 \quad 3.1 .4$ Educational level, farm size and herd size}

4 There is also a significant relationship between the level of education attained and the size 5 of farm land cultivated $\left(\mathrm{Chi}^{2} \mathrm{p}<0.001\right)$. As shown in table $2,34.2 \%$ of the respondents with 6 no formal education cultivated relatively larger farms in the category of $>5$ hectares and 1-5 7 hectares. On the other hand, none of the respondent with tertiary education which 8 represented $15 \%$ of the sample tested cultivated above 5 hectares.

\section{$9 \quad$ Placement of Table 2}

There was also a significant relationship between educational level and herd size $(p<0.05)$. This is more evident among respondents with a herd size of 10-50 animals. As seen in table 3 , the number of respondents with a herd size of 10-50 animals decreases with an increase in educational level. Animals raised by indigenous respondents include cattle, sheep, goats, chickens and pigs.

\section{Placement of Table 3}

Although no extensive research has been conducted to determine the relationship between education, farm size and herd size in Nigeria, it can be deduced from the results that because farming tends to be the primary source of income for uneducated respondents, they tend to cultivate larger parcels of land as well as diversify their incomes by raring more animals than respondents who have increased opportunities of securing non-farming employment because they have attained some level of formal education.

\subsubsection{Educational level and primary occupation} a significant relationship between educational level and primary occupation $\left(\mathrm{Chi}^{2} \mathrm{p}<0.001\right)$. As seen in Table 4 there were 65 respondents with farming as their primary occupation, $56.9 \%$ of them had no education, $26.2 \%$ had primary education, $16.9 \%$ had secondary education and none of the respondents with tertiary education had farming as a primary education. This shows that the number of respondents with farming as a primary occupation decreases with an increase in the level of education attained.

\section{Placement of Table 4}

These results are consistent with the findings of Espig (1992) who opined that farmers abandon farming as their educational level increases. Julius (2013) also argued that most farmers with, at least, primary education do not engage in agriculture as a main occupation and farmers without formal education depend mainly on agriculture for their income and 
1 livelihood. The research reveal that other primary and secondary occupations which Gbagyi

2 and Bassa respondents engage in include teaching, nursing, catering, security guarding,

3 motorcycle riding, shoe mending, weaving, fire wood trading, pottery, carving and

4 commercial driving.

$5 \quad 3.2$ Socio-cultural characteristics of the indigenous groups in relation to traditional food systems

6

7

Data extracted from the focus group discussion was coded using the NVivo9 software under a number of different conceptual headings discussed in this section.

For the purpose of this analysis, traditional food system is defined as

"All food within a particular culture that is available from local natural resources and culturally accepted. It also includes the sociocultural meanings, acquisition/processing techniques, use, compositions and nutritional consequences for the people using the food" (Kuhnlein and Receveur, 1996)

Observations and communications with elders of both the Gbagyi and Bassa indigenous groups in the study area revealed that these two groups have very similar traditional food systems. These observations are consistent with Filaba (2007) who found that the Gbagyi and all other indigenous groups in the FCT including the Bassa's grow and consume the same type of food crops as well as share similar food production system and consumption practices. They added that there was a cordial relationship between all indigenous groups in the FCT because of the similar culture they share.

The major food security crop for both indigenous groups is guinea corn (Sorghum bicolor), also known as "ewyi" in the Gbagyi dialect and "ohiu" in the Bassa dialect. According to the FAO West Africa food composition table, guinea corn is an energy crop rich in carbohydrate, protein and fibre. Guinea corn is also rich in various micronutrients as shown in table 5 below.

Guinea corn was described by the Sarkin Noma (Chief Farmer among the Bassa people) as "the king of all foods" because it is consumed in various forms in the morning, afternoon and night by the indigenous people of FCT. He also added that in times of ill health, guinea corn is made into pap (a semi-solid liquid) or Kunu (a liquid drink) both of which are believed to facilitate recovery. Pap and kunu are also famous weaning foods used among FCT indigenes as well as the whole of West Africa in general (Onofiok and Nnanyelugo, 1998).

The belief that guinea corn is the main sustaining food was also affirmed by a Gbagyi indigene named Kuchazi who said that "no matter what we eat, it's only food made from guinea corn that gives us true satisfaction". He explained that because they are mostly 
1 farmers, they eat azhe- a stiff porridge - made from guinea corn early in the morning before

2 engaging in their farming activities. When consumed in the morning, this azhe sustains them

3 till the return home in the evening. Other traditional food crops produced and consumed by

$4 \quad$ indigenes are presented in table 5.

$5 \quad$ Placement of Table 5

$6 \quad$ 3.2.1 Food production, processing, preparation and consumption practices a. Food production and processing

8 The food production roles of FCT indigenous men and women have changed over the years.

9 According to Ogundele (2004), in the past, farming was strictly a role for men while food processing, preparation, presentation as well as firewood cutting was done by women. However, the research revealed that women now actively engage in farming. According to the Sarkin noma (Chief farmer) of a Bassa village

"Women now farm as much as men do, to the point that some women realise better harvest than men. The yields and income they earn from sales of their produce is theirs to do as the wish".

He also expressed that due to the divide in farming activities, men and women now live relatively separate lives in terms of farm management decisions and income. However, this can be seen as a means of income decentralisation and a means of ensuring continuous food security in the household. Since men and women farm separately, in the case of yield failure on one farm, the household can still be food secure through the food and income obtained from the other farm.

Grain processing is mostly done by women and female children. There are several steps involved in grain processing which are both time and energy consuming. After the grain has been harvested and threshed, it is put in a wooden mortal, sprinkled with little water and pounded lightly to separate the grain coat from the grain, it is then air dried, washed and dried again to obtain chaff-free grain. Grain grinding was commonly done on a flat stone to obtain flour. The finer flour is separated to make the stiff porridge (azhe) while the residue (shibia) is used to make a semi-stiff porridge called pete or Kyai in bassa dialect. This residue is also added when making bean porridge. However, recently, grain grinding is done using a grain grinding machine which has become a business enterprise for indigenous women who provide this service.

Older female indigenes believe that younger indigenes are more inclined to accepting modern and foods from migrant cultures (see table 6) because of how tedious grain 
processing tends to be compared to the ease and shorter time it takes to prepare moderns foods like noodles, spaghetti or tea. Tnucheyi a 63 year old Gbagyi woman said that;

"In the past, because grain processing was something we had to do in order to feed our families, we found ways to make it interesting such as singing, but today because there are other types of foods, our children do not find as much joy when processing grain, they feel it is hard work"

\section{Placement of Table 6}

\section{b. Food preparation and consumption}

Food preparation is also mostly done by women and female children. Word frequency queries in the NVIVO analysis revealed that the favourite food among older indigenes is Tuwo, Zhepwo and Jehun, all made from guinea corn, and pounded yam. Other foods which they enjoy include amala (made from yam peels) and garri (made from cassava) both eaten with local soups. The Gbagyi and Bassa indigenes have evolved a means of preserving their food especially the stiff porridge made from guinea corn-tuwo. During the preparation of tuwo, ash from the firewood being used cook is added into the boiling water before the guinea corn, millet or corn flour is added. This ash preserves leftover tuwo for up to two weeks with it going bad.

Two food consumption patterns were observed among Gbagyi and Bassa indigenes. Larger polygamous families practiced the household-communal eating pattern especially during their evening meal. This however largely depends on the relationship among members of households explained Lanisha - 50 year old Bassa woman. Most households are polygamous and it is common for children of each wife to come together and share a meal or for all children to eat together - sometimes from the same bowl, depending on the agreement among wives. It was also noticed that men within a compound ${ }^{5}$ would gather to eat together, while women did the same. When asked the reason for their household- communal eating culture, Awyetalumilo - a 34 year old Gbagyi indigene said

"Eating together keeps us close as a family, it gives us a chance to talk to each other and share experiences every day. It is part of our culture"

It is also very common for outsiders who arrive during a meal to be offered a plate of food and asked to join the family meal. Therefore food is always prepared in large quantities to make allowances for visitors.

\footnotetext{
${ }^{5}$ A compound is defined as a group of dwelling units sharing common facilities including entrance, toilets, kitchen and eating area (Mai and Shamsuddin, 2012)
} 
1 The second eating practice observed was the individual eating pattern mostly practiced in

2 families where the household was not part of a "compound". Individuals within this

3 household had their meals at various times during the day depending on their individual

4 schedules. These families were also observed to live in houses built with modern building

5 materials like concrete blocks, unlike most traditional houses which are built with mud bricks.

6 This observation is consistent with the findings of Mai and Shamsuddin (2012) who also

7 observed a change in the social order and eating practices of Gbagyi households as their

8 building patterns changed to emulate modern housing.

\subsubsection{Rituals, customs and ceremonies}

Among all traditional foods consumed by Gbagyi and Bassa indigenes, guinea corn not only has nutritional importance but also has cultural significance. In the past, marriage was strictly by betrothal and a young man seeking a girls hand in marriage was required to work on the girl's father's farm for seven years and also provide grains - especially guinea corn for her to be fed and fattened before the wedding day. When there is more than one suitor, a farming competition is organised to select the stronger of the two. In recent times however, this tradition has been replaced with the payment of a dowry including boxes of clothing, assorted food items and modern drinks.

The Agbamaya festival is a celebrated by the Gbagyi at the beginning of the raining season to welcome the rain, while Zhibaje is a festival celebrate to mark the harvest of guinea corn and also celebrated to mark the first rains (Filaba, 2007). During these festivals, a locally brewed beer called brukutu made from fermented guinea corn is commonly drunk.

\subsection{Development and indigenous food culture (NVIVO)}

\subsubsection{Forms of development directly influencing indigenous food culture} Using the query function to identify word frequencies in the NVivo9 analysis, the research was able to identify the forms of development which the indigenous groups believe have directly influenced their food culture. The highest word frequencies include education, immigration, new forms of employment, roads, land tenure, trade, roads and religion.

As seen from the results in section 3.1.1 majority of both Gbagyi and Bassa indigenes have attained at least primary education. Education is accompanied with an exposure to other cultures and behaviour patterns (Pam, 2014).Tthis could encourage the modification and in some cases the erosion of indigenous culture. Expressing his concern, a 68 year old Gbagyi indigene- Shekwoduza- said that;

"Our children now go to school but do not learn about their culture there, we try to make sure they eat our traditional foods but they now prefer modern 
foods. Children should be taught in school that their traditional foods are good and not something to they should be ashamed of'.

Furthermore, the relocation of the Federal Capital Territory from Lagos to Abuja resulted in the immigration of many people with different cultural backgrounds into the area (Filaba, 2007). This has also significantly influenced the types of foods eaten by the indigenes as well as some of their food preparation techniques. Mwaboyi, a Gbagyi indigene said that;

"Now that we have many people from different places living among us, I have learnt to eat okpa from the Igbos, amala from the Yoruba's and masa from the Hausa's. I now use palm oil in making my soup like the Igbo's and Yoruba's do"

The relocation of the FCT to Abuja also facilitated the creation of new forms of white and blue collar jobs especially with Federal ministries, local government offices, hospitals, schools and private businesses. These jobs have attracted many indigenes especially the youth who more educated than older indigenes. This has facilitated the interaction between indigenous youth and youths from migrant cultures (Mai and Shamsuddin, 2012). As a result, their eating habits, mode of dressing and mannerism have also been significantly influenced. Tozabeyi, 78 year old Bassa indigene who explained that;

"Before Abuja became the FCT, we did not see the need for schools, we taught our children our culture, but development now makes our traditional methods of education look like it is not good enough. If we want our children to become "big people" they have to go to school. They now mix with other people, behave differently and eat different foods"

As mentioned in section 3.1.6, there was a significant relationship between education and primary occupation. The higher the educational level the less likely the indigene was to engage in farming as a primary occupation and the lower the educational level the more likely the indigene was to engage in farming as a primary occupation.

Religion is another factor that has contributed to the modification of the food culture among the Gbagyi and Bassa indigenes. Muslim respondents accounted for $44.2 \%$ of the total sample size, and all indicated that they do not eat pork because of religious laws. However, non-Muslim indigenes who accounted for $53.3 \%$ of the total sample size indicated that raise pigs and eat pork as part of their source of livelihood and nutrition. Also Christianity forbids the use of traditional healing rituals and foods prepared for the purposes of restoring health by native doctors (Falola, 2001). Traditionalists, who are 
1 neither Muslim nor Christian, accounted for $2.5 \%$ of the total sample and indicated that

2 they only constrained by traditional taboos, most of which forbid the consumption of 3 snakes, monkeys and bats. However, Christian and Muslim respondents also indicated

4 that they do not eat foods which are also traditionally forbidden such as snakes, monkeys 5 and bats.

6 Furthermore, the creation of new roads has improved access to market and expanded 7 trade opportunities. Common hot spots for trade include the Gwagwalada and Kuje 8 markets which hold their "market days" every four days. These markets attract traders 9 from different cultures selling indigenous, non-indigenous and modern food products, 10 thereby availing indigenes the opportunity to experiment with new foods.

\subsubsection{Indigenes perception of the impact of development on their traditional food systems}

Development from its inception should be human-oriented and take cognisance of the feltneeds of those groups that would be impacted by developmental processes (Nkechi and Paul, 2012). Without taking into account certain socio-cultural factors that tend to influence the ability of recipient's to fully take advantage and benefit from development activities, such development efforts may not be rightly described as "development" to those groups.

The field survey revealed that there was general agreement that development had influenced the traditional food systems of indigenous people in FCT. Indigenes perception of the impact of development on their traditional food systems fell into four categories. These are: indigenes not owning the land they cultivate, youth decreasing engagement in farming; changing roles of indigenous women and lack of government funding to support the promotion of traditional festivals.

The land tenure system in Nigeria vests the ownership of all urban land to the state government and ownership of rural land to the local government. However, all lands within the study area- Federal Capital Territory are vested exclusively in the Federal Government of Nigeria. This means that the indigenes do own the land they cultivate and live on but just have access to the land (Alarima, et al 2012).

"Our culture, our food and our traditions are tied to our land. Development has taken a lot of our land and given to other people, we have been made tenants on our own land. Without our land we have no culture". (Malaga-72, Bassa)

According to UN (2007), Indigenous peoples' connection to their traditional lands and territory is deeply rooted in their culture and history and also forms a core part of their spirituality and identity. Therefore, when they do not have complete ownership of their land, it rids them of an important aspect of their identity and culture. 
1 Focus Group discussions and key informant interviews revealed that young indigenes

2 increasingly prefer white collar jobs over farming. This seems to threaten the long term

3 sustainability of traditional food systems in the study area. As many young indigenes get

4 educated, they become exposed to the relatively easy way of life these white collar jobs and non-farming enterprises could provide. This makes them less inclined to engage in farming as a source of income because they want to be like the other young people they meet in cities.

I am worried that development has made our children more eager to live modern

In terms of income diversification and off farming season employment, most indigenous

Odia and Odia (2013) opined that the reduction in employment opportunities for Nigerian graduates is a call for youths to develop entrepreneurial skills as this will reduce their dependence on salaried employment. Therefore, indigenous youth who already have access to land are in a better position to earn a living from agriculture than migrant youths who face challenges in acquiring land for farming purposes in the FCT. Encouraging indigenous youth to engage in farming as a source of income will contribute to the sustainability of their traditional food system. women viewed development as a form of financial empowerment. Women now own businesses and engage in other less tedious jobs asides the usual farming, grain processing, weaving and carving. Although this empowerment has led to many women becoming key providers for their families, they see this as an opportunity to contribute meaningfully to the household.

"The change is good because I can do other things to support my family while I wait for my harvest. I own a shop and also do some cleaning jobs in the city. I have learnt to prepare other foods which do not take as much time to process like our traditional foods. This gives me the time I need to do other types of work and provide for my family" (Kukuta - 38, Bassa)

Filaba (2007) also explained that the empowerment of FCT indigenous women through income diversification avenues was borne out of earning low incomes from their faming activities as well as the negative health effect of farm labour. This made them keen to 
embrace the new forms of employment created by development so as to supplement their farm incomes.

Lastly, in terms of the sustainability of their traditional food system and culture, Focus group Discussions also revealed that indigenes are of the opinion that if they are encouraged to display their rich culture through festivals and cultural events, their children will have a better identity among migrant cultures and migrants will also have a better appreciation of the cultural heritage of FCT indigenous groups.

"I do not think development can completely take over our traditional foods or our land. Our culture has been around for many years and cannot die, but the government should encourage us by sponsoring our traditional festivals so we can show people our rich culture". (Donamu- 45 year old Gbagyi indigene)

It is not uncommon for the government to show support for indigenous culture. For instance, in Cross River state, Nigeria, the government sponsors the annual Calabar festival. This festival is an opportunity for indigenes to showcase their traditional dance, foods, attires and creativity. The festival is not done only among the indigenous groups in Cross River state, but is openly displayed on the streets for all to participate and appreciate. This festival has received international recognition and is believed to contribute to the sustainability of the Akwa lbom tradition and culture (Agba, 2013).

\section{Conclusion}

This research has been an expose on the impact of development on the traditional food systems of indigenous groups in FCT. The research found that the relocation of the Nigerian Federal Capital from Lagos to Abuja brought development in the form of education, roads, jobs and immigrants. These forms of development have modified the FCT indigenous food culture, resulting in some sort of hybrid traditional food system which now includes modern foods and non-indigenous traditional foods, both of which are contributing to the erosion of the indigenous food culture in FCT.

The study also highlight younger indigenous people are most influenced by development and are more likely to adopt new food cultures as they mix with people from other cultures and ethnic groups in schools, white collar jobs and through trade. As a result, it can be argued that the introduction of a new social order in the FCT has borne some sort of identity crisis among indigenous youth. This is also because they live in close proximity to a cosmopolitan city but are still a part of their indigenous society. As such they are mentally 
1 and physically exposed to a culture completely different from what they are born into and

2 strive to fit into the modern culture without losing their cultural identity.

3 The research identified that young female indigenes embrace other food ways because of 4 the difficulty in processing and preparing indigenous foods like guinea corn as opposed to 5 modern foods such as noodles that takes less than 10 minutes to prepare. This research 6 therefore recommends the incorporation of food and nutrition courses in adult education 7 classes to train women on easier grain processing techniques.

8 While over $60 \%$ of respondents were averse to change as they felt it was a threat to their culture, others had positive views about development especially with regards to income diversification, ease of food preparation, varieties of foods they now consumed and trade expansion. The traditional food system of both ethnic groups relegated women to food production, processing and preparation. But with development, women have diversified into other roles and embraced other food systems that do not require as much labour and time to prepare.

The research recommends that the Nigerian government should take advantage of the 2016 United Nations international year of pulses to initiate agricultural development projects to encourage indigenes to grow and consume more of their indigenous pulses especially the black eyed beans. This will not only supplement their high carbohydrate intake from guinea corn but will also promote nitrogen fixation and improved soil fertility on farmers' fields. However, it is important that implementing these development projects is informed by indigenous knowledge, respect traditional culture and focuses on the real needs of indigenous people. This will ensure that development efforts do not to change indigenous food ways by introducing new knowledge or techniques that do not agree with traditional systems.

The research also recommends that FCT indigenes should have more secure tittles to their land. Security of tenure is fundamental to Indigenous Peoples' cultural identity and security, and can be improved through acknowledgment of customary tenure and practices". The 2007 UN Declaration on the Rights of Indigenous Peoples and the 1989 ILO Convention No. 169 gives indigenous people the right to control their natural resources and also demands that states respect indigenous lands and territories (Woodley et al., 2009).

Finally, more research is required to explore the impact of the increasing market-demand for indigenous crops on the food and nutrition security of indigenes and also ascertain whether FCT indigenous groups are more susceptible to hidden hunger than migrant ethnic groups within the FCT. 


\section{Acknowledgements}

2 The Authors are thankful to the village heads of Baragda, Kaida, Shetugo and Chukuku for 3 granting her the permission to conduct this research in their communities. The translation 4 and extension support from Yohanna Masara, Simon Bulus, Billy Audu, Wambai Abubakar, 5 Dauda Salisu, Uche Iroha and Sam gwani are also duly acknowledged. The Authors are also 6 thankful to the African Fellowship Trust and the Royal Agricultural University, United $7 \quad$ Kingdom for their funding and research support.

\section{8}

9 


\section{References}

1. Adama, O., (2007). Governing from above: solid waste management in Nigeria's new capital city of Abuja. Ph.D. thesis, Stockholm University, Sweden

2. Agba, J. U (2013) The performing Arts and the carnival, Calabar: The implications for human rights protection in Nigeria. Journal of Humanities and Social Science. 11(4): 412

3. Ajah Julius (2013) Impacts of gender and farmers' level of education on access to agricultural extension services in Abuja, Nigeria. International Journal of Agricultural Economics and Extension. 1 (7): 55-60.

4. Alabi, T. and Alabi, O.S. (2014) Female education: A sociological analysis of girl-child education in Nigeria A. International Journal of Educational Policy Research and Review. $1(1): 6-13$

5. Alarima, C. I., Fabusor, E., Kolawole, A., Uzoma, K. C., Aromolarin, A. K., Masunaga, T., Wakatsuk, T., (2012) Land rights and rental systems: Implications for management of conflicts related to land in sawah-based rice production systems in Nigeria. African Study Monographs. 33(3): 189-208

6. Amuchie, A. A., Asotibe, N., and Audu, C. T (2015) An Appraisal of the Universal Basic Education in Nigeria. Journal of Poverty Investment and Development. 8:107-112

7. Arkkelin, D (2014) Using SPSS to Understand Research and Data Analysis. Psychology Curricular Materials. Book 1

8. Briones, A. E (2015) The impact of culture, religion and traditional knowledge on food and nutrition security in developing countries. FoodSecure Working Paper Series. 30:181

9. Chuwang, P.Z., Oyerinde, A.A and Emmanuel, H. (2014) Assessment of Cowpea (Vigna unguiculata:(L) Warp ) Production in Abuja Central Nigeria. Landmark research journal of Agriculture and Soil Sciences. 1(3): 32-36

10. Espig, A. F. (1992) Economics of Yam Production in Haryan. Indian Journal of Agricultural Economics. 92 (7): 28-34

11. Falola, T. (2001) Cultures and Customs of Nigeria. Greenwood Publishing Group

12. Filaba, M. A (2007) the empowerment of indigenous women in the Federal Capital Territory, Abuja Nigeria. Ethiopian Journal of Education and Science. 2 (2): 103-112

13. Food and Agriculture Organisation (2012) West Africa Food Composition Table. FAO, Rome

14. Hobblink, H. (2004) 'Biodiversity. What's at Stake? Currents. (35/36): 8-21 
15. Jimme, M.A; Gwamna, A.I. and Ikusemoran, M. (2015) Landuse and Landcover Change Detection in Kuje Area Council of the Federal Capital Territory (FCT), Abuja, Nigeria. IOSR Journal of Environmental Science, Toxicology and Food Technology. 9(10): 1-11

16. Julius, A. (2014) Perceptional evaluation of gender access to farm inputs in Abuja, Nigeria. Journal of Sustainable Development in Africa. 16:2

17. Kuhnlein, H.V.; Erasmus, B.; Spigelski, D.; Burlingame, B. (2013) Indigenous Peoples' Food Systems and Well-Being: Interventions and Policies for Healthy Communities; FAO: Rome, Italy; p. ix

18. Kuhnlein, H. V and Receveur, O. (1996) Dietary Change and Traditional Food Systems of Indigenous Peoples. Annual Review on Nutrition. 16:417-442

19. LeVan, C. A. and Olubowala, J (2014) I am here until development comes: Displacement, demolitions, and property rights in urbanizing Nigeria. African Affairs. 113(452): 387-408

20. Mai, M. M., and Shamsuddin, S (2012). Urbanisation and Globalisation of Gbagyi Housing Transformation. Putra: Universiti Teknologi Malaysia.

21. Mendez, M.A., Monteiro, C.A., Popkin, B.M. (2005) 'Overweight exceeds underweight among women in most developing countries'. American Journal of Clinical Nutrition. (81): 714-721.

22. Ministry of the Federal Capital Territory. (1998). Abuja Handbook. Lagos: Ministry of Federal Capital Territory

23. Ngodoo, A.C. and Idisi, P. O. (2014) inequality gaps: issues for smallholder farming in Nigeria International Journal of Humanities and Social Science. 4(11): 274-286

24. Nkechi, I.E and Paul, C. (2012) Social Services Administration in Gwagwalada Area Council: Militating Factors. Journal of Public Administration and Governance. 2(3): 159170

25. NPC (2006) Population and hosing census: Enumerators manual. Federal Republic of Nigeria, National Population Commission, Nigeria, pp:1-16

26. O'Connor, N., Farag, K. and Baines, R. (2016) What is food poverty? A conceptual framework. British Food Journa.l 118 (2) pp.429 - 449

27. Odia, J. O and Odia, A. A (2013) Developing entrepreneurial skills and transforming challenges into opportunities in Nigeria. Journal of Education and Social Research. 3(3): 289-298

28. Odumuh, T. O (2003) Adult Literacy as an Agent of Development among Rural Communities in Gwagwalada Area Council of F.C.T. Ilorin Journal of Education. 22: 126132 
29. Ogundele, S. O., (2004) some indigenous knowledge systems in parts of central Nigeria. International Journal of Traditional Knowledge. 5(1): 108-113

30. Olagunju, F.I., Fakayode, S. B., Babatunde, R. O. and Ogunwole-Olapade, F. (2012). Gender Analysis of Sweet Potato Production in Osun State, Nigeria. Asian Journal of Agricultural Extension, Economics and Sociology. 2(1): $1-13$.

31. Onofiok, N. O and Nnanyelugo, D. O (1998) Weaning foods in West Africa: nutritional problems and possible solutions. Food and Nutrition Bulletin. 19: 17-20

32. Pam, T. D. (2014) Rural-urban migration among youths in Nigeria: the impacts on agriculture and rural development. IOSR Journal of Humanities and Social Science. 19(3): 120-123

33. Pieters, H., Andrea G. and Anneleen V. (2013) Conceptual Framework for the Analysis of the Determinants of Food and Nutrition Security. FoodSecure Working Paper 13.

34. Smith, I.F. (2013) Sustained and integrated promotion of local, traditional food systems for nutrition security. In Diversifying Food and Diets: Using Agricultural Biodiversity to Improve Nutrition and Health; Fanzo, J., Hunter, D., Borelli, T., Mattei, F., Eds.; Earthscan: London, UK, 2013; pp. 122-139

35. United Nations (2007) Indigenous people's Land, Territories and Natural Resources. United Nations Permanent Forum on Indigenous Issues. http://www.un.org/en/events/indigenousday/pdf/Backgrounder LTNR FINAL.pdf

36. United Nations (2010) United Nations Office of the Special Adviser on Gender Issues and Advancement of Women and the Secretariat of the United Nations Permanent Forum on Indigenous Issues. Briefing note No. 3 http://bit.ly/1Raqv2i

37. Witte, R.S. and Witte, J.S. (2004). Statistics. 7th ed. USA: Jhon Wiley and Sons, Inc

38. Woodley, E. C., Pryck, E., and Carmen, A. (2009) Cultural indicators of Indigenous Peoples' food and agro-ecological systems. Sustainable Agriclture and rural development project. E/C.19/2009/CRP. 3 
Table 1: The relation of gender / age groups and Farm size

\begin{tabular}{|c|c|c|c|c|c|}
\hline & & \multicolumn{3}{|c|}{ Farm size } & \multirow[t]{2}{*}{ Total } \\
\hline & & $<1$ ha & $1-5$ ha & $>5$ ha & \\
\hline \multirow[t]{2}{*}{ Gender } & Male & $28 \%$ & $43 \%$ & $82 \%$ & $39 \%$ \\
\hline & Female & $72 \%$ & $57 \%$ & $18 \%$ & $61 \%$ \\
\hline \multirow[t]{3}{*}{ Age } & Below 30 & $23 \%$ & $4 \%$ & $0 \%$ & $13 \%$ \\
\hline & $30-50$ & $52 \%$ & $45 \%$ & $0 \%$ & $44 \%$ \\
\hline & above 50 & $25 \%$ & $51 \%$ & $100 \%$ & $43 \%$ \\
\hline
\end{tabular}




\section{ACCEPTED MANUSCRIPT}

Table 2: Relation between educational level and farm size

\begin{tabular}{|c|c|c|c|c|c|}
\hline & \multicolumn{3}{|c|}{ Farm size } & \multirow[t]{2}{*}{ Total } \\
\hline & & $<1$ ha & $1-5 \mathrm{ha}$ & $>5$ ha & \\
\hline \multirow[t]{5}{*}{ Education } & none & $20.0 \%$ & $40.8 \%$ & $81.8 \%$ & $34.2 \%$ \\
\hline & primary & $38.3 \%$ & $18.4 \%$ & $9.1 \%$ & $27.5 \%$ \\
\hline & secondary & $36.7 \%$ & $10.2 \%$ & $9.1 \%$ & $23.3 \%$ \\
\hline & tertiary & $5.0 \%$ & $30.6 \%$ & $0.0 \%$ & $15.0 \%$ \\
\hline & Total & $100.0 \%$ & $100.0 \%$ & $100.0 \%$ & $100.0 \%$ \\
\hline
\end{tabular}




\section{ACCEPTED MANUSCRIPT}

Table 3: Relation between education level and herd size

\begin{tabular}{rlrrr}
\hline \multirow{2}{*}{ Education } & & \multicolumn{2}{c}{ Herd size } & \multicolumn{1}{c}{ Total } \\
\cline { 3 - 4 } & & $<10$ heads & $>10$ heads & \\
\cline { 2 - 4 } & none & $15.6 \%$ & $45.3 \%$ & $\mathbf{3 4 . 2} \%$ \\
\cline { 2 - 4 } & primary & $37.8 \%$ & $21.3 \%$ & $\mathbf{2 7 . 5 \%}$ \\
\cline { 2 - 4 } & secondary & $33.3 \%$ & $17.3 \%$ & $\mathbf{2 3 . 3} \%$ \\
\cline { 2 - 4 } & tertiary & $13.3 \%$ & $16.0 \%$ & $\mathbf{1 5 . 0} \%$ \\
\hline \multicolumn{2}{c}{ Total } & $\mathbf{1 0 0 . 0 \%}$ & $\mathbf{1 0 0 . 0} \%$ & $\mathbf{1 0 0 . 0 \%}$ \\
\hline
\end{tabular}




\section{ACCEPTED MANUSCRIPT}

Table 4: Relation between educational level and primary occupation

\begin{tabular}{llccc}
\hline \multirow{2}{*}{ Education } & & \multicolumn{3}{c}{ Primary occupation } \\
\cline { 3 - 5 } & & farming & other & Total \\
\cline { 2 - 5 } & none & $56.9 \%$ & $7.3 \%$ & $\mathbf{3 4 . 2} \%$ \\
\cline { 2 - 5 } primary & $26.2 \%$ & $29.1 \%$ & $\mathbf{2 7 . 5} \%$ \\
\cline { 2 - 5 } & secondary & $16.9 \%$ & $30.9 \%$ & $\mathbf{2 3 . 3} \%$ \\
\cline { 2 - 5 } & tertiary & $0.0 \%$ & $32.7 \%$ & $\mathbf{1 5 . 0} \%$ \\
\cline { 2 - 5 } & Total & $\mathbf{1 0 0 . 0} \%$ & $\mathbf{1 0 0 . 0} \%$ & $\mathbf{1 0 0 . 0} \%$
\end{tabular}


ACCEPTED MANUSCRIPT

Table 5: Indigenous foods consumed with nutrient content (Adapted from: FAO, 2012)

\begin{tabular}{|c|c|c|c|c|c|c|c|}
\hline \multirow[b]{2}{*}{ Food type } & \multirow[b]{2}{*}{$\begin{array}{l}\text { Gwari } \\
\text { name }\end{array}$} & \multirow[b]{2}{*}{ Bassa name } & \multicolumn{5}{|c|}{ Nutritional Content } \\
\hline & & & $\begin{array}{l}\text { Energy } \\
\text { (kcal)KJ }\end{array}$ & $\begin{array}{l}\text { Protein } \\
\text { (g) }\end{array}$ & $\begin{array}{l}\text { Fat } \\
\text { (g) }\end{array}$ & $\begin{array}{l}\text { Carbohydrate } \\
\text { (g) }\end{array}$ & $\begin{array}{l}\text { Fibre } \\
\text { (g) }\end{array}$ \\
\hline \multicolumn{8}{|l|}{ Grain } \\
\hline Millet (raw) & Sari & Arshina & $(364) 1540$ & 8.8 & 5.8 & 64.8 & 9 \\
\hline $\begin{array}{l}\text { Maize, yellow, whole } \\
\text { kernel, dried, raw }\end{array}$ & Kamba & Akaraba & $(353) 1490$ & 9 & 4.5 & 64.3 & 9.7 \\
\hline Guinea corn (red) & Enyi/Enwi & Ohiu & $(348) 1470$ & 10.5 & 3.5 & 63.6 & 9.9 \\
\hline $\begin{array}{l}\text { Beniseed (sesame), } \\
\text { whole, dry, raw }\end{array}$ & Durgua & Gwaga & $(577) 2380$ & 18.2 & 48.9 & 10 & 11.8 \\
\hline Rice, native, raw, Hulled & Chenwi & Owere & (359)1520 & 7.4 & 2.2 & 77.3 & 0.4 \\
\hline Tubers & & & & & & 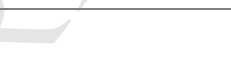 & \\
\hline Sweet potato, raw & Dunku & Otumriku & $(116) 490$ & 1.5 & 0.2 & 25.5 & 3 \\
\hline water yam, raw & Shyama & Akalabeh & $(125) 529$ & 2.4 & 0.1 & 26.5 & 4.1 \\
\hline water yam, raw & Shyama & Akalabeh & $(125) 529$ & 2.4 & 0.1 & 26.5 & 4.1 \\
\hline \multicolumn{8}{|l|}{ Animal products } \\
\hline $\begin{array}{l}\text { beef, meat, lean, raw, } \\
\text { boneless }\end{array}$ & Nagwo & Na'a/Ine & $(126) 528$ & 21.7 & 4.3 & 0 & 0 \\
\hline Goat meat (raw) & Enna & Biyoyo & $(165) 689$ & 17.5 & 10.6 & 0 & 0 \\
\hline $\begin{array}{l}\text { Pork, raw (approx. } 20 \% \\
\text { fat) }\end{array}$ & kusu & Sundokrusu & $(265) 1100$ & 16.8 & 22 & 0 & 0 \\
\hline Chicken, raw & Pyise & Alema & $(232) 962$ & 16.7 & 18.3 & 0 & 0 \\
\hline Guinea fowl (raw) & Azu & Alema/Iwo & $(232) 962$ & 16.7 & 18.3 & 0 & 0 \\
\hline Guinea pig (raw) & Zezetsu & Asun & $(265) 1100$ & 16.8 & 22 & 0 & 0 \\
\hline \multicolumn{8}{|l|}{ Forest Foods } \\
\hline Moringa & Zegele & Zegole & $(86) 364$ & 8.3 & 1.2 & 9.6 & 2 \\
\hline \multicolumn{8}{|l|}{ Legumes } \\
\hline locust beans & Chola & Gindo & $(445) 1860$ & 32.2 & 19.5 & 33 & 4.1 \\
\hline Cowpea & Ebuwi & Gwageshege & $(316) 1340$ & 21.2 & 1.3 & 47.2 & 15.3 \\
\hline \multicolumn{8}{|l|}{ Oils } \\
\hline Soya oil & Soyami & Soya goje & $(900) 3700$ & 0 & 100 & 0 & 0 \\
\hline \multicolumn{8}{|l|}{ Vegetables } \\
\hline Spinach & Alefo & Afa & $(28) 115$ & 2.8 & 0.6 & 1.7 & 2.2 \\
\hline Garden Eggs & Okun & Enyor & $(30) 125$ & 1.1 & 0.2 & 4.6 & 2.6 \\
\hline \multicolumn{8}{|l|}{ Fruits } \\
\hline 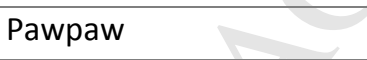 & Kambuli & Tukomburu & $(36) 151$ & 0.5 & 0.1 & 7.3 & 1.9 \\
\hline Cashew & Kashina & Kassiu & $(56) 235$ & 1 & 0.7 & 10.7 & 1.5 \\
\hline Guava & Gwava & Gwava & $(57) 238$ & 1 & 0.4 & 9.5 & 5.6 \\
\hline \multicolumn{8}{|l|}{ Nuts } \\
\hline Bambara nut, dried & Ebu/Afhi & Gwoje Kape & $(376) 1590$ & 20.1 & 5.9 & 58.9 & 3.7 \\
\hline \multicolumn{8}{|l|}{ Drinks } \\
\hline Local Beer (guinea corn) & Ede & Mayaga/Loca & (31)128 & 0.5 & Trace & 2.7 & 0.1 \\
\hline
\end{tabular}


Table 6: Modern and Non-indigenous traditional foods consumed by FCT indigenes

\begin{tabular}{l|lll} 
NAME OF FOOD & CATEGORY & CLASS & REGION \\
\hline INDOMIE & Noodles & Modern & General \\
SPAGETTI & Pasta & Modern & General \\
COKE, FANTA, SPRITE & Soft fizzy drinks & Modern & General \\
GUINNESS, STAR, GIN & Alcoholic drinks & Modern & General \\
OKPA, MOI-MOI, AKARA & Bean cakes & Traditional & Igbo/ Yoruba culture \\
AMALA & Stiff porridge & Traditional & Yoruba culture \\
MASA & Rice cake & Traditional & Hausa culture \\
BISCUITS, CAKES, PIES & Snacks & Modern & Global \\
GOLDEN MORN & Cereal & Modern & General \\
TEA & Beverage drink & Modern & General
\end{tabular}




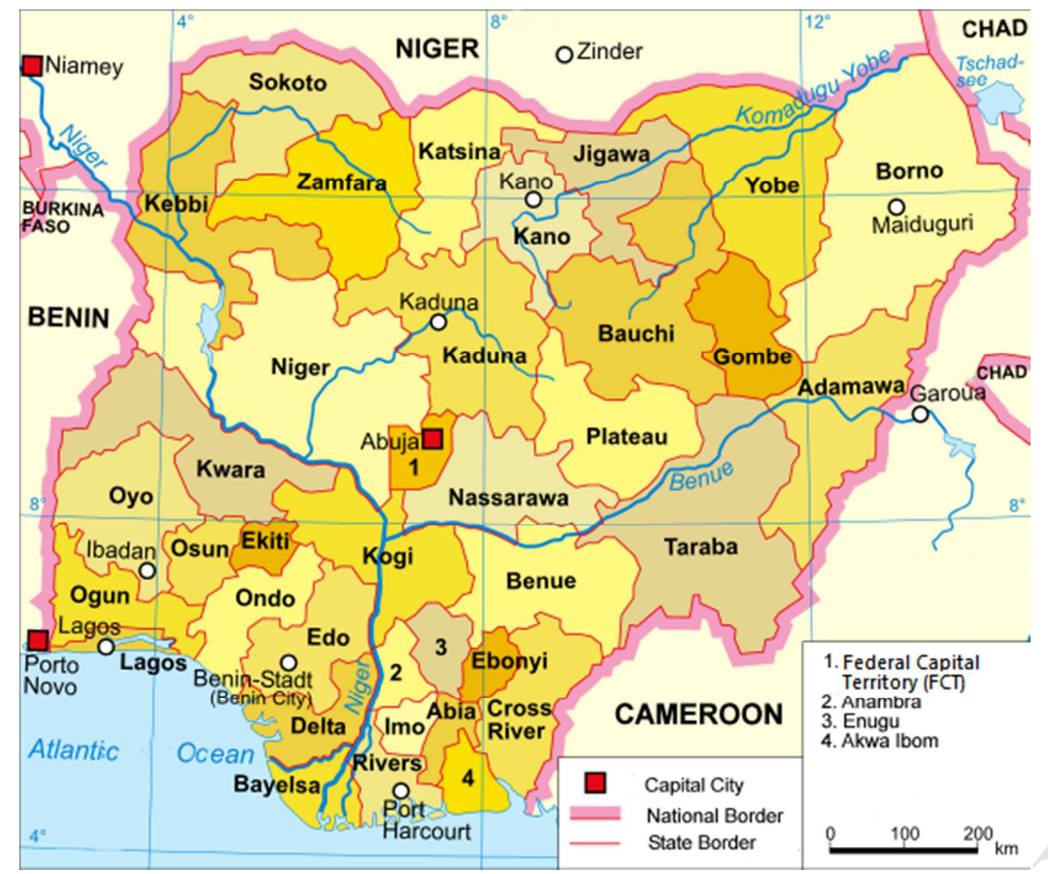

Figure 1: Map of Nigeria showing the $\mathbf{3 6}$ states and the Federal Capital Territory. (Released under the GNU Free Documentation License) 


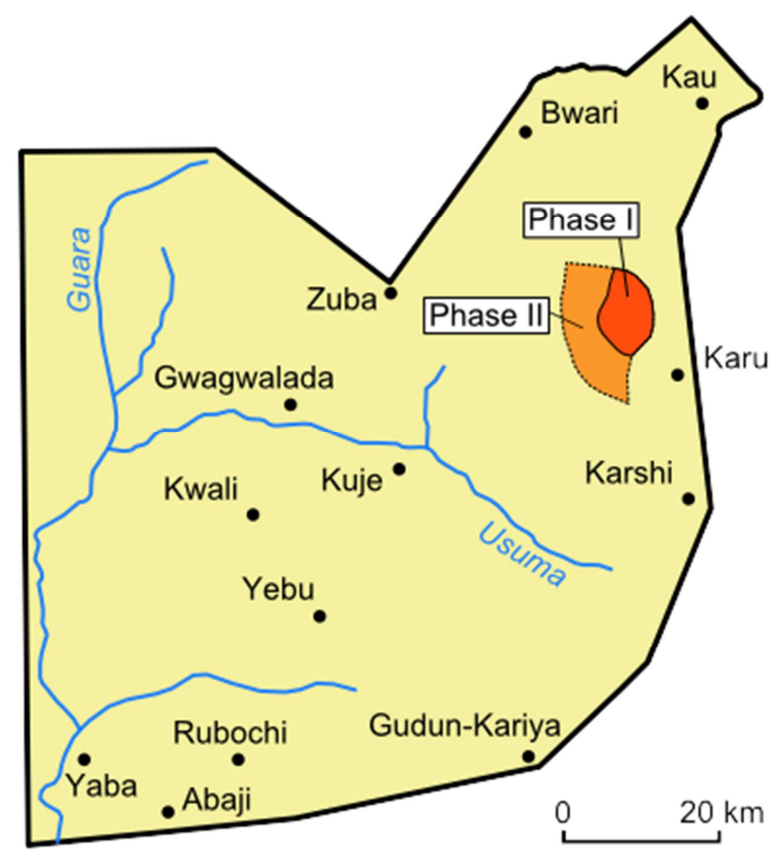

Figure 2: Map of the Federal Capital Territory showing the main councils. (Released under the GNU Free Documentation License) 


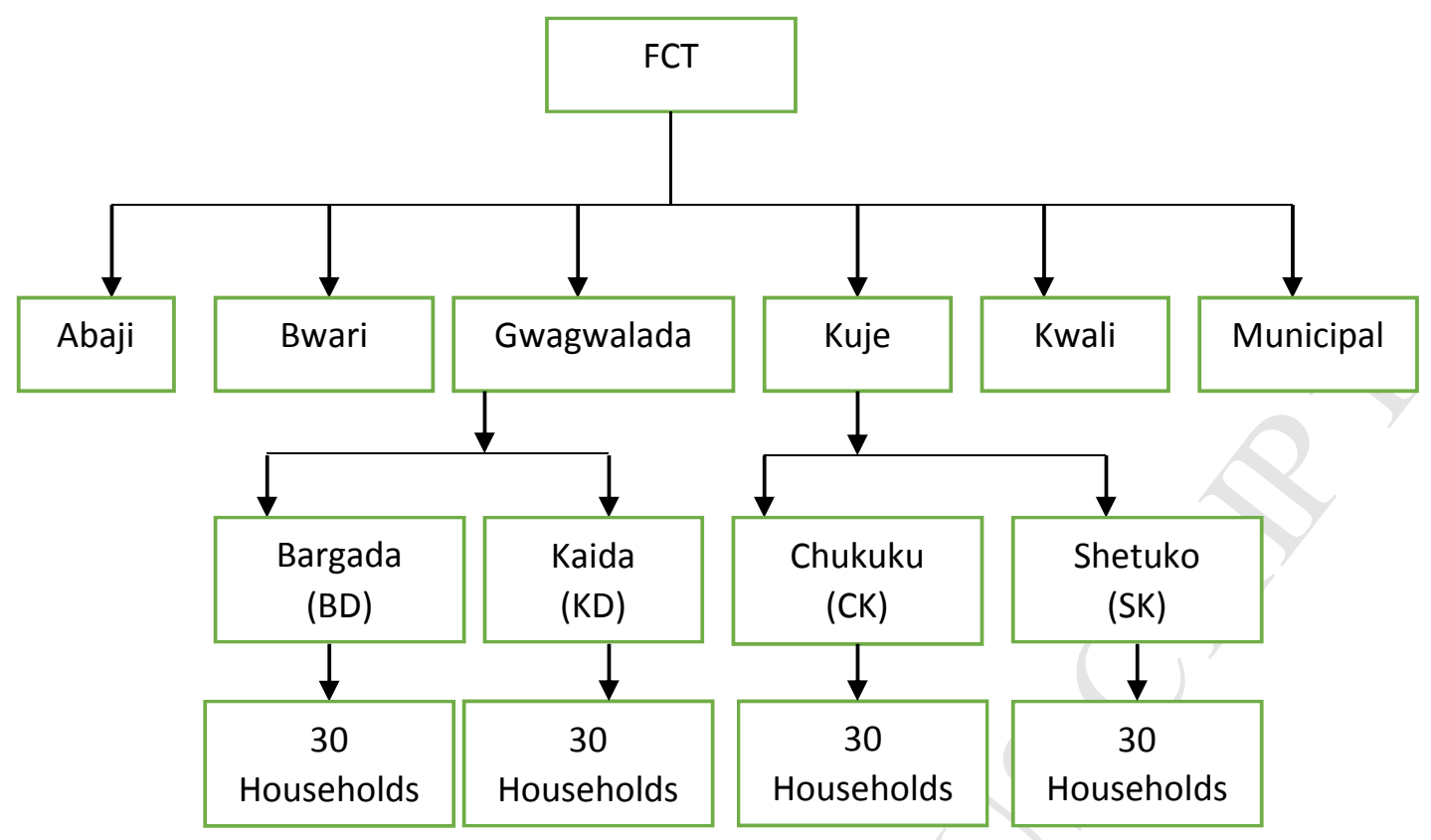

Figure 3: Stepwise selection of area councils, indigenous communities and respondents within the study area 
a

$$
40
$$

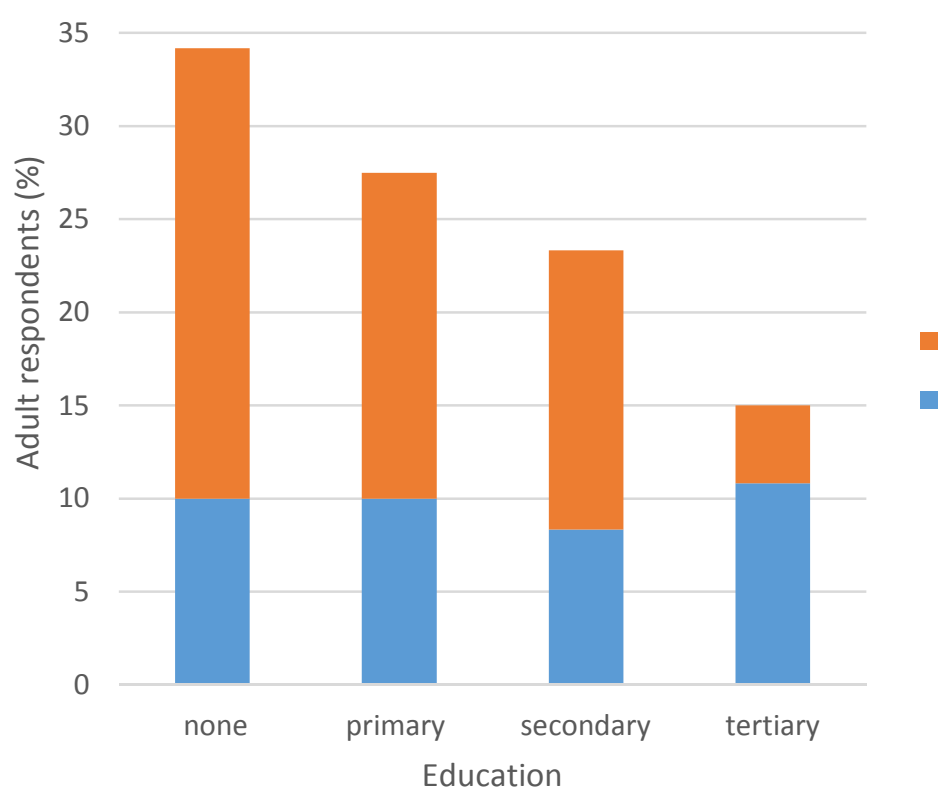

b

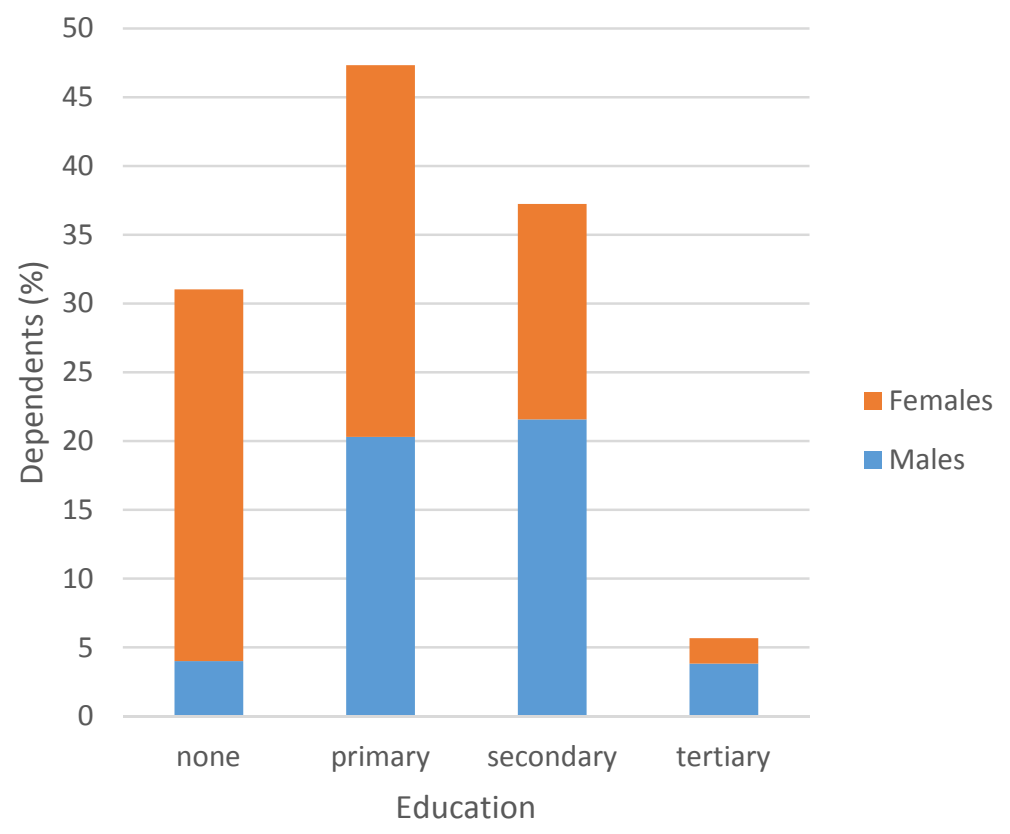

Figure 4: The relationship between gender and educational level of adult respondents (a) and dependents (b) 